\title{
Characterization of natural variation for zinc, iron and manganese accumulation and zinc exposure response in Brassica rapa $\mathrm{L}$.
}

\author{
Jian Wu • Henk Schat • Rifei Sun • \\ Maarten Koornneef • Xiaowu Wang • \\ Mark G. M. Aarts
}

Received: 7 September 2006 / Accepted: 13 December 2006 / Published online: 17 January 2007

(C) Springer Science+Business Media B.V. 2007

\begin{abstract}
Brassica rapa L. is an important vegetable crop in eastern Asia. The objective of this study was to investigate the genetic variation in leaf $\mathrm{Zn}, \mathrm{Fe}$ and $\mathrm{Mn}$ accumulation, $\mathrm{Zn}$ toxicity tolerance and $\mathrm{Zn}$ efficiency in B. rapa. In total 188 accessions were screened for their Zn-related characteristics in hydroponic culture. In experiment 1, mineral assays on 111 accessions grown under sufficient $\mathrm{Zn}$ supply $\left(2 \mu \mathrm{M} \quad \mathrm{ZnSO}_{4}\right)$ revealed a variation range of $23.2-155.9 \mu \mathrm{g} \mathrm{g}^{-1}$ dry weight (d. wt.) for $\mathrm{Zn}, 60.3-350.1 \mu \mathrm{g} \mathrm{g}^{-1} \mathrm{~d}$. wt. for Fe and 20.9-53.3 $\mu \mathrm{g} \mathrm{g}^{-1} \mathrm{~d}$. wt. for the Mn concentration in shoot. The investigation of tolerance to excessive $\mathrm{Zn}\left(800 \mu \mathrm{M} \mathrm{ZnSO}_{4}\right)$ on 158 accessions, by using visual toxicity symptom parameters (TSPs), identified different levels of tolerance in B. rapa. In experiment 2, a selected sub-set of accessions from experiment 1 was characterized
\end{abstract}

J. Wu $\cdot$ M. Koornneef · M. G. M. Aarts $(\square)$

Laboratory of Genetics, Wageningen University,

Arboretumlaan 4, 6703 BD Wageningen,

The Netherlands

e-mail: mark.aarts@wur.nl

$\mathrm{J}$. Wu $\cdot$ R. Sun $\cdot$ X. Wang

Institute of Vegetables and Flowers,

Chinese Academy of Agricultural Sciences,

Zhongguancun South Street 12, Beijing, 100081, China

H. Schat

Ecology and Physiology of Plants, Faculty of Biology,

Vrije Universiteit, De Boelelaan 1085,

1081 HV Amsterdam, The Netherlands in more detail for their mineral accumulation and tolerance to excessive $\mathrm{Zn}$ supply $(100 \mu \mathrm{M}$ and $\left.300 \mu \mathrm{M} \mathrm{ZnSO}_{4}\right)$. In this experiment $\mathrm{Zn}$ tolerance (ZT) determined by relative root or shoot dry biomass varied about 2 -fold. The same six accessions were also examined for $\mathrm{Zn}$ efficiency, determined as relative growth under $0 \mu \mathrm{M} \mathrm{ZnSO} 4$ compared to $2 \mu \mathrm{M} \mathrm{ZnSO}$. $\mathrm{Zn}$ efficiency varied 1.8-fold based on shoot dry biomass and 2.6-fold variation based on root dry biomass. $\mathrm{Zn}$ accumulation was strongly correlated with $\mathrm{Mn}$ and $\mathrm{Fe}$ accumulation both under sufficient and deficient $\mathrm{Zn}$ supply. In conclusion, there is substantial variation for $\mathrm{Zn}$ accumulation, $\mathrm{Zn}$ toxicity tolerance and $\mathrm{Zn}$ efficiency in Brassica rapa L., which would allow selective breeding for these traits.

Keywords Brassica rapa $\mathrm{L}$. $\cdot$ Mineral accumulation $\cdot \mathrm{Zn}$ excess tolerance .

Zn efficiency

\section{Introduction}

Zinc $(\mathrm{Zn})$ is an essential micronutrient required by all organisms for its role in many physiological processes as a structural or catalytic component of proteins. Unfortunately $\mathrm{Zn}$ deficiency is a widespread problem by affecting humans in case of $\mathrm{Zn}$ shortage in food. About $20 \%$ of rural children are at risk of inadequate $\mathrm{Zn}$ intake in China 
(Ma et al. in press). $\mathrm{Zn}$ deficiency is also affecting crops in case of poor $\mathrm{Zn}$ availability in soil. In China $\mathrm{Zn}$ deficiency is prevalent on calcareous soil in North China and calcareous alluvial soils of the Middle and Lower Yangtse River valley (Liu 1994). Breeding and growing of crops with high $\mathrm{Zn}$ content and $\mathrm{Zn}$ efficiency are promising and sustainable approaches to solve the Zn deficiency problems in humans and soil (Cakmak et al. 1996).

Knowledge on genetic variation of $\mathrm{Zn}$ accumulation and $\mathrm{Zn}$ efficiency is the prerequisite for breeding of $\mathrm{Zn}$ content/efficiency-improved crop cultivars. Previous studies on genetic variation of micronutrients were mainly limited to staple food crops, including wheat (Graham et al. 1997), rice (Graham et al. 1999), bean (Beebe et al. 2000) and maize (Banziger and Long 2000). Little is known about micronutrient content in leaves, which is the main edible organ of leafy vegetables (Kopsell et al. 2004). The ability of a genotype to grow and yield well in soils that are too deficient in $\mathrm{Zn}$ for a standard cultivar to grow and yield well, is defined as $\mathrm{Zn}$ efficiency (Graham et al. 1992). Progress has been made in screening $\mathrm{Zn}$ efficient genotypes and understanding the physiological and biochemical mechanisms of $\mathrm{Zn}$ efficiency (Reviewed in Hacisalihoglu and Kochian 2003). However, knowledge on Zn efficiency in vegetables is limited (Hacisalihoglu et al. 2004).

Brassica rapa L. comprises several cultivar types producing edible roots, stems, leaves, buds or flowers as vegetables (Gomez-Campo and Prakash 1999). Some of these are the most important vegetables in eastern Asia, especially in China, Korea and Japan, both in terms of production and per capita consumption (Opena et al. 1988). As vegetables are one of the main micronutrient sources of the population in China (Ma et al. in press), we studied $B$. rapa vegetables to collect more information on the extent of genotypic variation for $\mathrm{Zn}$ accumulation and $\mathrm{Zn}$ efficiency and their potential for genetic improvement of these traits.

While a shortage of $\mathrm{Zn}$ is a problem for plant growth, an excess of $\mathrm{Zn}$ is even more detrimental. $\mathrm{Zn}$ heavy metal pollution is prevalent in China's industrialized areas (Liu et al. 2005; Nan and
Zhao 2000). B. rapa is not known to be a metal hyperaccumulator and showed a significant decrease in biomass with increased root and shoot $\mathrm{Zn}$ concentration upon exposure to toxic $\mathrm{Zn} \mathrm{lev-}$ els (Ebbs and Kochian 1997; Coolong and Randle 2003; He et al. 2004). However, in general only one accession was tested in each case. We therefore intended to determine the natural variation for excess $\mathrm{Zn}$ tolerance $(\mathrm{ZT})$ among $B$. rapa germplasm.

The objective of this study is to characterize the genotypic variation for $\mathrm{Zn}$ accumulation and $\mathrm{Zn}$ response in $B$. rapa upon exposure to different $\mathrm{Zn}$ concentrations. Understanding the range of genotypic variation in $\mathrm{Zn}$ accumulation and response to $\mathrm{Zn}$ nutritional stress will provide a genetic basis for micronutrient and $\mathrm{Zn}$ stress tolerance breeding of $B$. rapa vegetables and for further genetic studies on $\mathrm{Zn}$ accumulation and tolerance to $\mathrm{Zn}$ nutritional stress.

\section{Materials and methods}

\section{Plant material}

To determine the genetic variation of $\mathrm{Zn}$ accumulation and response to $\mathrm{Zn}$ stress, a total of 188 Brassica rapa accessions belonging to nine cultivar groups (Table 1) were screened. About 184 accessions were obtained from the Institute of Vegetables and Flowers of the Chinese Academy of Agricultural Sciences (IVF-CAAS); two were obtained from the Dutch Crop Genetic Resources Centre (CGN) in Wageningen, and the other two were obtained from Dr. T. Osborn (University of Wisconsin, Madison, USA). About 111 accessions were used for shoot (aboveground tissue) mineral analysis and 158 lines were screened for their tolerance to $\mathrm{Zn}$ excess stress. On the basis of their performance in this large scale screening experiment (experiment 1), 15 accessions were selected for a detailed accumulation and tolerance testing (experiment 2) as described below. In experiment 2, six additional accessions were added, which are the parents of additional doubled haploid (DH) populations that are under development. 
Table 1 Overview of $B$. rapa accessions, according to cultivar group used in the described experiments

\begin{tabular}{|c|c|c|c|c|c|c|}
\hline \multirow[t]{3}{*}{ Cultivar group } & \multirow[t]{3}{*}{ Total } & \multicolumn{5}{|c|}{ No. of accessions } \\
\hline & & ZA & & $\mathrm{ZT}$ & & $\mathrm{ZE}$ \\
\hline & & \multicolumn{2}{|c|}{$\operatorname{Exp} 1 \operatorname{Exp} 2$} & \multicolumn{2}{|c|}{$\operatorname{Exp} 1 \operatorname{Exp} 2$} & \\
\hline $\begin{array}{l}\text { Chinese cabbage } \\
\text { (sp. pekinensis) }\end{array}$ & 69 & 45 & 7 & 46 & 1 & 1 \\
\hline $\begin{array}{l}\text { Pak Choi } \\
\text { (sp. Chinensis) }\end{array}$ & 64 & 39 & 6 & 61 & 2 & 2 \\
\hline $\begin{array}{l}\text { Caixin } \\
\text { (sp. parachinensis) }\end{array}$ & 23 & 15 & 1 & 23 & 1 & 1 \\
\hline $\begin{array}{l}\text { Turnip } \\
\text { (sp.rapa) }\end{array}$ & 11 & 6 & 1 & 10 & & \\
\hline $\begin{array}{l}\text { Wutacai } \\
\text { (sp. narinosa) }\end{array}$ & 8 & 4 & 1 & 8 & 1 & 1 \\
\hline $\begin{array}{l}\text { ZiCaitai } \\
\text { (sp. chinensis } \\
\text { var. purpurea) }\end{array}$ & 5 & 2 & 1 & 5 & & \\
\hline $\begin{array}{l}\text { Mizuna } \\
\text { (sp. nipposinica) }\end{array}$ & 6 & 4 & 2 & 5 & 1 & 1 \\
\hline $\begin{array}{l}\text { Oil seed } \\
\text { (Yellow Sarson) } \\
\text { (sp.tricolaris) }\end{array}$ & 1 & 1 & 1 & & & \\
\hline Rapid cycling & 1 & 1 & 1 & & & \\
\hline Total & 188 & 117 & 21 & 158 & 6 & 6 \\
\hline
\end{tabular}

$\mathrm{ZA}: \mathrm{Zn}$ accumulation experiment; ZT: $\mathrm{Zn}$ tolerance experiment; ZE: Zn efficiency experiment; Exp 1: experiment 1; Exp 2: experiment 2

\section{Plant culture}

For experiment 1, three plants for each accession were grown in a greenhouse without climate control in Beijing, China, from mid March till May. The environmental conditions were $20-30^{\circ} \mathrm{C} / 10$ $15^{\circ} \mathrm{C}$ (day/night temperature), 30,000-40,000 Lux light intensity and $50-60 \%$ relative humidity. Seeds were germinated in vermiculite and watered every 3 days with half-strength Hoagland's nutrient solution after germination. After 14 days (mineral accumulation experiment) or 7 days ( $\mathrm{Zn}$ tolerance experiment) seedlings were transferred to hydroponic culture trays each containing three individuals from 24 accessions in 201 half-strength Hoagland's nutrient solution. The solution was buffered with $2 \mathrm{mM}$ MES (2-morpholinoethanesulphonic acid) at $\mathrm{pH}$ 5.5. A concentration of $2 \mu \mathrm{M} \mathrm{ZnSO}_{4}$ was used as sufficient $\mathrm{Zn}$ supply. Nutrient solutions were replaced once a week until harvesting. After 7 days at sufficient $\mathrm{Zn}$, plants for the ZT experiment were transferred to excess $\mathrm{Zn}$ nutrient solution containing $800 \mu \mathrm{M}$ $\mathrm{ZnSO}_{4}$, and were exposed for 14 days. The solution was refreshed after 1 week.

For experiment 2, plants were grown in a climate-controlled growth cabinet set at $75 \%$ humidity and $22 / 16^{\circ} \mathrm{C}(16 \mathrm{~h} / 8 \mathrm{~h})$ day/night temperature regime. Seeds were germinated in fertilized potting soil watered with tap water. Seedlings were transferred to hydroponic solution after 14 days for the mineral accumulation experiment or after 7 days for the ZT and Zn efficiency experiments. For the mineral accumulation experiment plants were grown for 14 days in medium with sufficient $\mathrm{Zn}(2 \mu \mathrm{M} \mathrm{ZnSO})$. For the $\mathrm{ZT}$ experiment plants were first grown for 7 days in medium with sufficient $\mathrm{Zn}(2 \mu \mathrm{M}$ $\mathrm{ZnSO}_{4}$ ) before exposure to excess $\mathrm{Zn}$ for 14 days. Instead of the very high concentration of $800 \mu \mathrm{M} \mathrm{ZnSO}$, plants were transferred to 100 and $300 \mu \mathrm{M} \mathrm{ZnSO}$ as excess $\mathrm{Zn}$ concentrations and to $2 \mu \mathrm{M} \mathrm{ZnSO}$ as the sufficient $\mathrm{Zn}$ control. For the $\mathrm{Zn}$ efficiency experiment, one-week-old germinated seedlings were transferred directly to a nutrient solution without $\mathrm{ZnSO}_{4}$ or with $2 \mu \mathrm{M}$ $\mathrm{ZnSO}_{4}$ as control and grown for 15 days before assessment. For each line three pots were used with one plant per pot for the mineral accumulation experiment and three plants per pot for the $\mathrm{Zn}$ efficiency and ZT experiments. In all these experiments the nutrient solutions were refreshed twice a week.

\section{Mineral determination}

In experiment 1 , shoots were harvested from plants with a similar size after 27-36 days of growth. For each accession shoots from 2 to 3 individual plants were combined in one sample. Harvested shoots were washed with de-ionized water and lyophilized. Samples were ground by mortar and pestle before wet-digestion in concentrated $\mathrm{HNO}_{3}: \mathrm{HClO}_{4}(87: 13, \mathrm{~V} / \mathrm{V})$ subsequently at $60^{\circ} \mathrm{C}$ for $3 \mathrm{~h}, 100^{\circ} \mathrm{C}$ for $1 \mathrm{~h}, 120^{\circ} \mathrm{C}$ for $1 \mathrm{~h}$ and $195^{\circ} \mathrm{C}$ for $2.5 \mathrm{~h}$. The digests were diluted with $5 \mathrm{ml} 20 \% \mathrm{HCl}$ and deionized $\mathrm{H}_{2} \mathrm{O}$ to a final volume of $20 \mathrm{ml}$ before analysis by inductively coupled plasma-atomic emission spectrometer (ICP-AES) (Leeman-DRE DR6009, USA) at the IVF-CAAS in Beijing. 
In experiment 2, shoots and roots were harvested separately per plant. After oven-drying at $65^{\circ} \mathrm{C}$ for 3 days, shoot and root dry biomass were measured. Shoot samples were ground by mortar and pestle before wet-digestion in concentrated $\mathrm{HCl}: \mathrm{HNO}_{3}(1: 4, \mathrm{~V} / \mathrm{V})$ at $140^{\circ} \mathrm{C}$ for $7 \mathrm{~h}$. Mineral assays were performed by using a flame Atomic Absorption Spectrometer (AAS) (model 1100, Perkin-Elmer) at the Vrije Universiteit, Amsterdam. Seed mineral content of the 21 accessions used for experiment 2 was determined in samples of about $100 \mathrm{mg}$ ground seeds. Seed mineral determination assays were as described for shoots.

\section{Zn efficiency and tolerance}

Shoots and roots were harvested separately and dried at $65^{\circ} \mathrm{C}$ for 3 days to determine their dry biomass. Zn efficiency (ZE) was calculated for shoots and roots based on relative biomass production using the following calculation: $\mathrm{ZE}$ $(\%)=[$ dry biomass at $0 \mu \mathrm{M} \mathrm{Zn/dry} \mathrm{biomass} \mathrm{at}$ $2 \mu \mathrm{M} \mathrm{Zn}] * 100 \%$.

In the first ZT experiment, a ranked set of five Toxicity Symptom Parameters (TSPs) representing different levels of deterioration of the leaves was used to score plant response after exposure to $800 \mu \mathrm{M} \mathrm{ZnSO}_{4}: 1=$ slight chlorosis of leaves, plant is still growing; $2=$ chlorosis of leaves; $3=$ severe chlorosis of leaves, leaves started withering; $4=$ most of the leaves seared; $5=$ plant has died. Accessions with mean TSP values below 2 were classified as $\mathrm{Zn}$ tolerant and above 4 as $\mathrm{Zn}$ sensitive.

For the second ZT experiment, ZT was calculated in two different ways. One calculation was made based on dry root or shoot biomass: $\mathrm{ZT}_{\text {bio- }}$ mass $(\%)=[$ dry biomass at toxic level Zn/dry biomass at $2 \mu \mathrm{M} \mathrm{Zn]} * 100 \%$. Another calculation was based on root elongation during exposure. For this analysis, roots were dyed with active charcoal before transferring plants to excess $\mathrm{Zn}$ medium. Root elongation during exposure (nonstained part of the root) was measured according to Schat and Ten Bookum (1992): $Z_{\text {root }}$ $(\%)=[$ root elongation at toxic level $\mathrm{Zn} /$ root elongation at $2 \mu \mathrm{M} \mathrm{Zn]} * 100 \%$.
Statistics

Statistical analyses of metal concentration and root length were conducted using one-way ANOVA followed by the Student-Neuman-Keuls posthoc analysis (SigmaStat, SPSS Science, Chicago, IL, USA). The variation within the mean is presented as the standard error. Significance of correlation was determined using simple linear regression. We considered differences significant at $P \leq 0.05$.

\section{Results}

\section{Zn, Fe and Mn accumulation}

When examining the shoot $\mathrm{Zn}$ concentration for 111 accessions, belonging to seven cultivar groups of B. rapa, grown in hydroponic culture with sufficient $\mathrm{Zn}$ supply for about 4 weeks, large variations were found between accessions, ranging from 23.2 to $155.9 \mu \mathrm{g} \mathrm{Zn} \mathrm{g}^{-1} \mathrm{~d}$. wt. (Fig. 1a). Accessions with a $\mathrm{Zn}$ concentration lower than $50 \mu \mathrm{g} \mathrm{g}^{-1} \mathrm{~d}$. wt., between 50 and $100 \mu \mathrm{g} \mathrm{g}^{-1} \mathrm{~d}$. wt. and above $100 \mu \mathrm{g} \mathrm{g}^{-1} \mathrm{~d}$. wt. accounted for respectively $37 \%, 56 \%$ and $7 \%$ of the total. The same samples were used to determine the $\mathrm{Fe}$ and $\mathrm{Mn}$ concentrations. The Fe concentration varied from 60.3 to $350.1 \mu \mathrm{g} \mathrm{g}^{-1} \mathrm{~d}$. wt. (Fig. 1b). Accessions with a $\mathrm{Fe}$ concentration lower than $100 \mu \mathrm{g} \mathrm{g}^{-1} \mathrm{~d}$. wt., between 100 and $200 \mu \mathrm{g} \mathrm{g}^{-1} \mathrm{~d}$. wt. and above $200 \mu \mathrm{g} \mathrm{g}^{-1} \mathrm{~d}$. wt. accounted respectively for $28 \%, 71 \%$ and $1 \%$ of the total. The $\mathrm{Mn}$ concentration ranged from 20.9 to $53.3 \mu \mathrm{g} \mathrm{g}^{-1} \mathrm{~d}$. wt. (Fig 1c). The proportions of accessions with a $\mathrm{Mn}$ concentration lower than $30 \mu \mathrm{g} \mathrm{g}^{-1} \mathrm{~d}$. wt., between 30 and $50 \mu \mathrm{g} \mathrm{g}^{-1} \mathrm{~d}$. wt. and above $50 \mu \mathrm{g} \mathrm{g}^{-1} \mathrm{~d}$. wt. were respectively $28 \%, 69 \%$ and $3 \%$ of the total. There was no significant difference in average $\mathrm{Zn}$ or $\mathrm{Fe}$ concentration between the different cultivar groups, however the average Mn concentrations in Wutacai and Mizuna accessions were significantly higher compared to those of the other cultivar groups (Table 2). Zn concentration varied most in Wutacai with a variation coefficient as high as $60 \%$. 
Fig. 1 Genotypic

variation of shoot $\mathrm{Zn}(\mathbf{a})$,

$\mathrm{Fe}$ (b) and Mn (c) concentrations of $111 \mathrm{~B}$. rapa accessions grown in halfstrength Hoagland's nutrient solution containing $2 \mu \mathrm{M} Z \mathrm{Zn}$ for 27-36 days. Data are based on a mixed sample of 2-3 plants per accession. Accessions are ordered according to increasing mineral content (a)

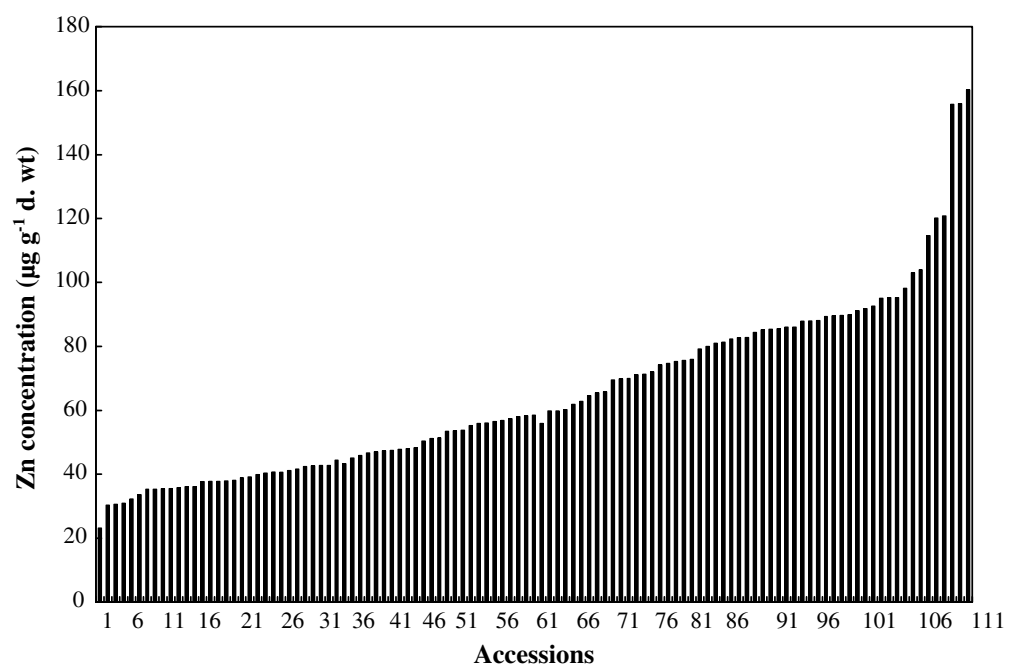

(b)

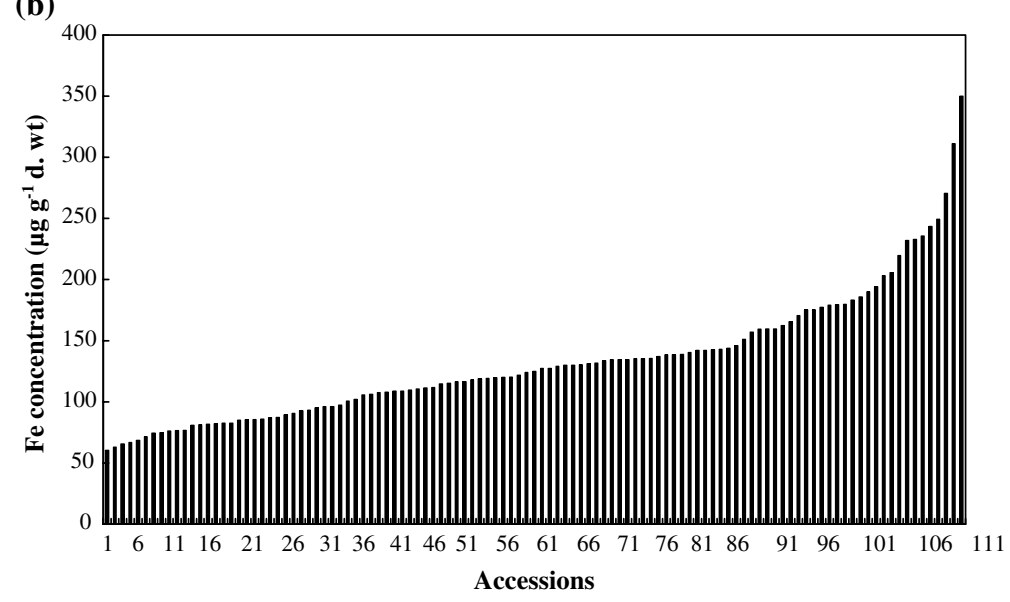

(c)

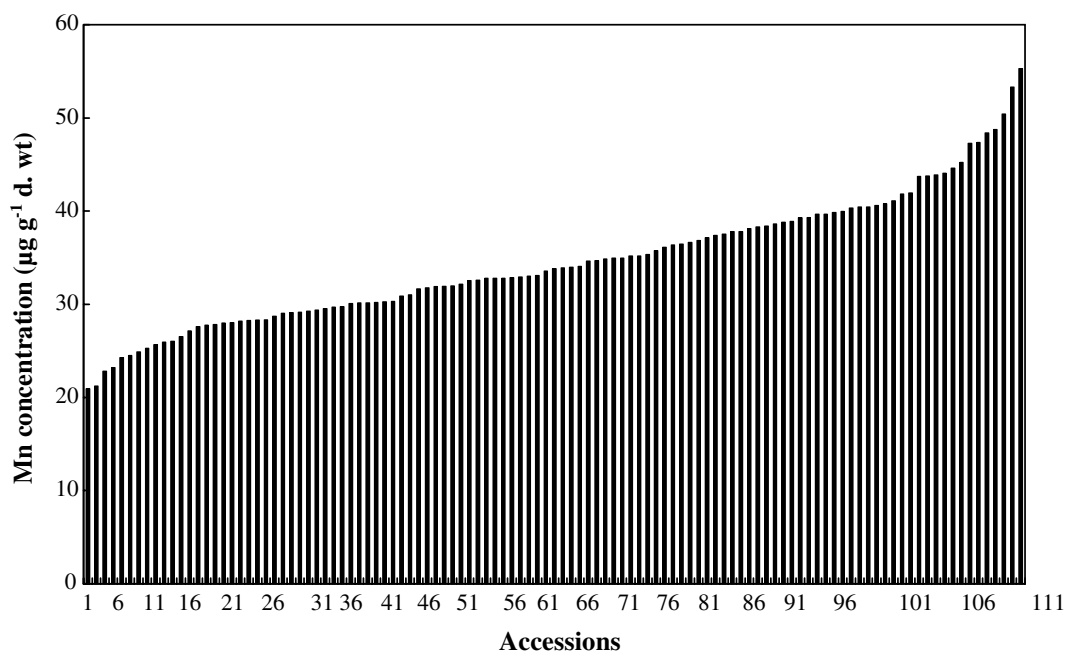


Table 2 Average $\mathrm{Zn}$, Fe and Mn concentrations ( $\mu \mathrm{g} \mathrm{g}^{-1} \mathrm{~d}$. wt.) in shoots of a number of $B$. rapa accessions (No. acc.) according to cultivar groups

\begin{tabular}{|c|c|c|c|c|}
\hline Cultivar group & No. acc. & $\mathrm{Zn}$ & $\mathrm{Fe}$ & Mn \\
\hline $\begin{array}{c}\text { Chinese cabbage } \\
\text { (sp. pekinensis) }\end{array}$ & 44 & $60 \pm 30$ & $142 \pm 50$ & $32 \pm 7 b$ \\
\hline $\begin{array}{l}\text { Pak Choi } \\
\text { (sp. chinensis) }\end{array}$ & 37 & $69 \pm 24$ & $118 \pm 46$ & $34 \pm 5 b$ \\
\hline $\begin{array}{l}\text { Caixin } \\
\text { (sp.parachinensis) }\end{array}$ & 15 & $60 \pm 21$ & $125 \pm 72$ & $37 \pm 5 b$ \\
\hline $\begin{array}{l}\text { Wutacai } \\
\text { (sp. narinosa) }\end{array}$ & 4 & $83 \pm 50$ & $153 \pm 48$ & $45 \pm 7 a$ \\
\hline $\begin{array}{l}\text { Turnip } \\
\text { (sp.rapa) }\end{array}$ & 5 & $44 \pm 10$ & $145 \pm 48$ & $39 \pm 6 b$ \\
\hline $\begin{array}{l}\text { Mizuna } \\
\text { (sp. nipposinica) }\end{array}$ & 3 & $75 \pm 10$ & $142 \pm 37$ & $44 \pm 5 a$ \\
\hline $\begin{array}{l}\text { ZiCaitai } \\
\text { (sp. chinensis } \\
\text { var. purpurea) }\end{array}$ & 2 & $80 \pm 15$ & $185 \pm 67$ & $34 \pm 0 b$ \\
\hline
\end{tabular}

All plants were grown in half-strength Hoagland's nutrient solution containing $2 \mu \mathrm{M} \mathrm{ZnSO}$. Data are presented as means $\pm \mathrm{SE}$ Only for $\mathrm{Mn}$ significant differences $(P \leq 0.001)$ were found between the cultivar groups as indicated by different letters. Significance was determined by ANOVA followed by Student Neuman-Keuls posthoc analysis

Five accessions with low $\mathrm{Zn}$ concentration (on average $40 \mu \mathrm{g} \mathrm{g}^{-1} \mathrm{~d}$. wt.), four accessions with moderate $\mathrm{Zn}$ concentration (on average $67 \mu \mathrm{g} \mathrm{g}^{-1} \mathrm{~d}$. wt.) and six accessions with high $\mathrm{Zn}$ concentration (on average $135 \mu \mathrm{g} \mathrm{g}^{-1} \mathrm{~d}$. wt.) were selected for further confirmation in a subsequent experiment, with plants grown under climate-controlled conditions (Experiment 2). Six additional accessions, which are the parents of recently developed DH populations, were also included. In experiment 2 , the range of $\mathrm{Zn}$ concentration was slightly less (43.5-135.0 $\mu \mathrm{g} \mathrm{g}^{-1} \mathrm{~d}$. wt.) than in experiment 1 (Table 3 ). The mean $\mathrm{Zn}$ concentration was comparable in both experiments. In general, the $\mathrm{Fe}$ concentration was lower in experiment 2 compared to experiment 1 (ranging from 40.4 to $70.6 \mu \mathrm{g} \mathrm{g}^{-1} \mathrm{~d}$. wt.), whereas it was the reverse for the $\mathrm{Mn}$ concentration (ranging from 44.5 to $113.4 \mu \mathrm{g} \mathrm{g}^{-1} \mathrm{~d}$. wt.). The data from the two experiments were not significantly correlated $\left(R^{2}=0.10\right.$ for $\mathrm{Zn}, 0.06$ for $\mathrm{Fe}$ and 0.24 for $\left.\mathrm{Mn}\right)$. When comparing the 21 accessions, the Fe concentrations were not significantly different, but there were significant differences for the $\mathrm{Zn}$ and Mn concentrations (Table 3). The $\mathrm{Zn}, \mathrm{Fe}$ and $\mathrm{Mn}$ concentrations of these accessions were positively correlated (Fig. 2). The correlation between $\mathrm{Zn}$ and $\operatorname{Mn}\left(R^{2}=0.58, P \leq 0.001\right)$ was much higher than that of $\mathrm{Zn}$ and $\mathrm{Fe}\left(R^{2}=0.19, P \leq 0.05\right)$, however, when excluding the data of outlier accession L144 from the data set, the correlation between $\mathrm{Zn}$ and $\mathrm{Fe}$ concentrations was significant at $P \leq 0.005 \quad\left(R^{2}=0.47\right)$. Omitting this accession from the correlation analysis did not affect the significance level for the correlation between $\mathrm{Zn}$ and Mn concentrations $\left(R^{2}=0.67, P \leq 0.001\right)$ or $\mathrm{Fe}$ and $\mathrm{Mn}$ concentrations $\left(R^{2}=0.43, P \leq 0.005\right)$. In addition to shoot mineral concentration, the seed weight, seed mineral content and plant biomass were determined for these accessions (Table 4). When comparing the shoot mineral concentration to the dry shoot or root biomass (Table 4), shoot Fe concentration was positively correlated with dry shoot biomass $\left(R^{2}=0.32, P \leq 0.05\right)$ and root biomass $\left(R^{2}=0.34, P \leq 0.05\right)$, while neither $\mathrm{Zn}$ concentration nor Mn concentration was correlated with biomass. There was no significant correlation between shoot concentration and content per seed for $\mathrm{Zn}$ and Fe (Table 4), however, a significant correlation was found for seed Mn content and shoot Mn concentration $\left(R^{2}=0.25\right.$, $P \leq 0.05)$.

\section{Zn tolerance}

Although B. rapa is not known to be particularly tolerant to excess $\mathrm{Zn}$ exposure, we assessed the initial set of 158 accessions for their tolerance to $800 \mu \mathrm{M} \mathrm{ZnSO}_{4}$ exposure for 14 days (Experiment 1). Tolerance was determined using TSPs, and tolerant, average and sensitive accessions accounted for respectively $8 \%, 45 \%$ and $46 \%$ of the total (Fig. 3). Exposure to $800 \mu \mathrm{M} \mathrm{ZnSO}$ is rarely encountered by plants in the field. To determine if comparable results could be obtained when exposing plants to less extreme $\mathrm{Zn}$ concentrations, two tolerant accessions (L56w and L86w), three average accessions (L58w, L64w and L203w) and one sensitive accession (L66w) were used in experiment 2. In this experiment, plants were exposed to $2 \mu \mathrm{M} \mathrm{ZnSO}_{4}$ as normal $\mathrm{Zn}$

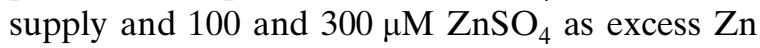
supply. Zn tolerance was determined in terms of dry biomass production rather than with TSPs 
Fig. 2 Correlations between shoot $\mathrm{Zn}$, Fe and Mn concentrations of 21 selected accessions grown in half-strength Hoagland's nutrient solution with $2 \mu \mathrm{M} \mathrm{ZnSO}_{4}$ for 14 days. (a) Correlation between shoot $\mathrm{Zn}$ and $\mathrm{Fe}$ concentrations. (b) Correlation between shoot $\mathrm{Zn}$ and $\mathrm{Mn}$ concentrations. (c) Correlation between shoot Fe and Mn concentrations. Correlation between shoot $\mathrm{Zn}$ and $\mathrm{Fe}$ concentrations was significant at $P \leq 0.005$

$\left(R^{2}=0.47\right)$ when excluding the low $\mathrm{Fe}$ outlier L144. *,** and *** are statistically significant at $P \leq 0.05, P \leq 0.005$ and $P \leq 0.001$ levels respectively. Significance was determined by simple linear regression; $R^{2}=$ squared linear regression coefficient (a)

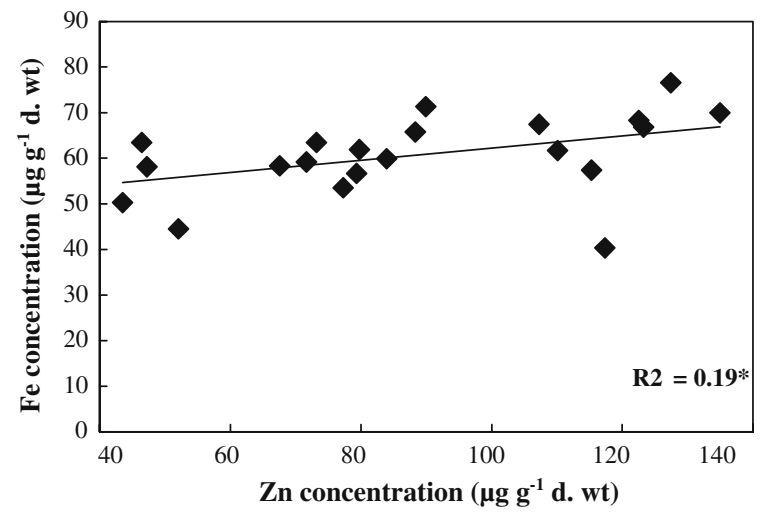

(b)

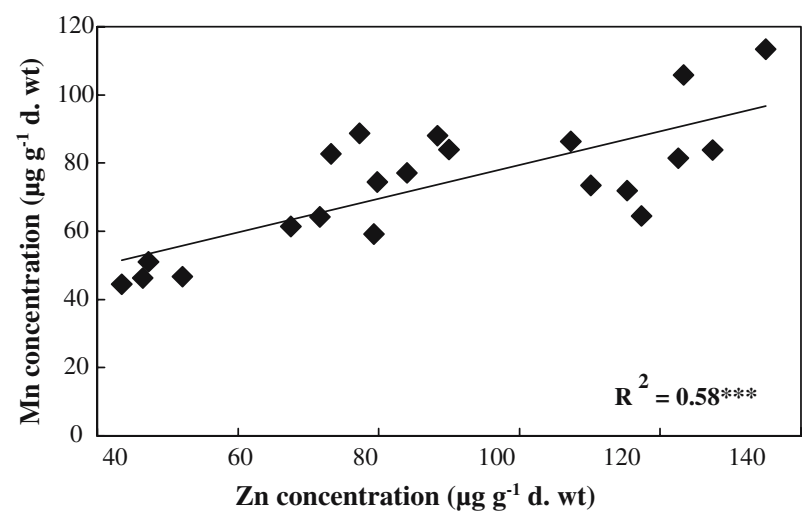

(c)

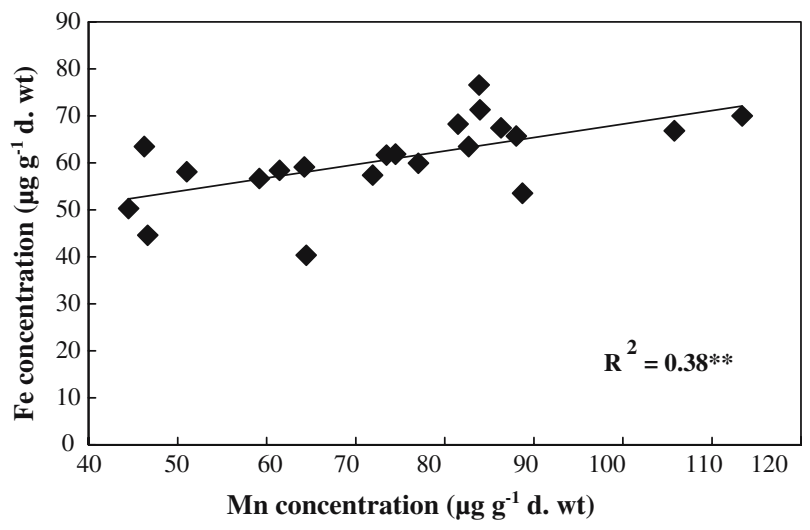

$300 \mu \mathrm{M} \mathrm{ZnSO}$. A comparable range was found for ZT based on root dry biomass. In line with the initial selection based on TSP values, the two tolerant accessions L56w and L86w maintained a high relative shoot growth at $300 \mu \mathrm{M} \mathrm{Zn}(94 \%)$, whereas the sensitive accession L66w showed
(Table 5). As expected, biomass was reduced when plants were grown at high $\mathrm{Zn}$ concentrations and the growth inhibition increased along with the increase in $\mathrm{Zn}$ concentration (Table 5). ZT based on shoot dry biomass varied almost 2fold among accessions at both $100 \mu \mathrm{M}$ and 
Table 3 Comparison of $\mathrm{Zn}, \mathrm{Fe}$ and $\mathrm{Mn}$ concentrations ( $\mu \mathrm{g} \mathrm{g}^{-1}$ d. wt.) in shoots of 21 selected $B$. rapa accessions (Acc.) for experiments 1 and 2

\begin{tabular}{|c|c|c|c|c|c|c|c|}
\hline \multirow[t]{2}{*}{ Cultivar group } & \multirow[t]{2}{*}{ Acc } & \multicolumn{2}{|l|}{$\mathrm{Zn}$} & \multicolumn{2}{|l|}{$\mathrm{Fe}$} & \multicolumn{2}{|l|}{$\mathrm{Mn}$} \\
\hline & & Exp 1 & $\operatorname{Exp} 2$ & Exp 1 & $\operatorname{Exp} 2$ & Exp 1 & $\operatorname{Exp} 2$ \\
\hline \multirow[t]{7}{*}{ Chinese Cabbage } & L107w & 104 & $127 \pm 1 \mathrm{ab}$ & 244 & $77 \pm 6 \mathrm{a}$ & 40 & $84 \pm 10$ ae \\
\hline & L113w & 160 & $107 \pm 7$ ae & 127 & $68 \pm 6 a$ & 38 & $86 \pm 5 \mathrm{ad}$ \\
\hline & L64w & 57 & $80 \pm 6$ ae & 90 & $62 \pm 3 \mathrm{a}$ & 29 & $75 \pm 2$ ce \\
\hline & L127w & 120 & $79 \pm 16$ ae & 203 & $57 \pm 1 \mathrm{a}$ & 28 & $59 \pm 6 \mathrm{ce}$ \\
\hline & L140w & 156 & $72 \pm 3$ be & 87 & $59 \pm 4 \mathrm{a}$ & 40 & $64 \pm 5$ ce \\
\hline & L23w & 48 & $52 \pm 3 \mathrm{de}$ & 134 & $45 \pm 3 \mathrm{a}$ & 37 & $47 \pm 0 \mathrm{de}$ \\
\hline & L146 & n.d. & $46 \pm 3 \mathrm{e}$ & n.d. & $64 \pm 13 \mathrm{a}$ & n.d. & $46 \pm 7 \mathrm{de}$ \\
\hline \multirow[t]{6}{*}{ Pak Choi } & L196w & 156 & $135 \pm 12 \mathrm{a}$ & 151 & $70 \pm 5 \mathrm{a}$ & 47 & $113 \pm 2 \mathrm{a}$ \\
\hline & L86w & 64 & $123 \pm 10 \mathrm{ac}$ & 168 & $67 \pm 2 \mathrm{a}$ & 50 & $106 \pm 4 \mathrm{ab}$ \\
\hline & L66w & 48 & $123 \pm 4 \mathrm{ac}$ & 160 & $68 \pm 5 a$ & 38 & $82 \pm 3$ ae \\
\hline & L175 & n.d. & $115 \pm 21 \mathrm{ac}$ & n.d. & $57 \pm 4 \mathrm{a}$ & n.d. & $72 \pm 2$ be \\
\hline & L67w & 115 & $110 \pm 13 \mathrm{ad}$ & 157 & $62 \pm 7 \mathrm{a}$ & 34 & $73 \pm 7$ be \\
\hline & L78w & 23 & $90 \pm 1 \mathrm{ae}$ & 98 & $71 \pm 0 \mathrm{a}$ & 23 & $84 \pm 7 \mathrm{ae}$ \\
\hline \multirow[t]{2}{*}{ Mizuna } & L203w & 42 & $68 \pm 1 \mathrm{ce}$ & 160 & $58 \pm 4 \mathrm{a}$ & 39 & $61 \pm 2$ ce \\
\hline & L19 & n.d. & $44 \pm 6 \mathrm{e}$ & n.d. & $50 \pm 6 \mathrm{a}$ & n.d. & $45 \pm 4 \mathrm{e}$ \\
\hline Wutacai & L56w & 41 & $88 \pm 2 \mathrm{ae}$ & 110 & $66 \pm 3 \mathrm{a}$ & 38 & $88 \pm 3 \mathrm{ac}$ \\
\hline Caixin & L58w & 71 & $73 \pm 4$ be & 117 & $64 \pm 2 \mathrm{a}$ & 34 & $83 \pm 7 \mathrm{ae}$ \\
\hline Zi Caitai & L62w & 76 & $84 \pm 5 \mathrm{ae}$ & 90 & $60 \pm 6 a$ & 37 & $77 \pm 5 \mathrm{ae}$ \\
\hline Yellow Sarson & L143 & n.d. & $77 \pm 7 \mathrm{ae}$ & n.d. & $54 \pm 5 \mathrm{a}$ & n.d. & $89 \pm 10 \mathrm{ac}$ \\
\hline Rapid cycling & L144 & n.d. & $117 \pm 6$ ac & n.d. & $40 \pm 2 \mathrm{a}$ & n.d. & $64 \pm 10$ ce \\
\hline Turnip & L115 & n.d. & $47 \pm 6 \mathrm{e}$ & n.d. & $58 \pm 5 \mathrm{a}$ & n.d. & $51 \pm 3$ ce \\
\hline Correl & & 0.10 & & 0.06 & & 0.24 & \\
\hline Mean & & 85 & 89 & 102 & 61 & 37 & 74 \\
\hline
\end{tabular}

The accessions are arranged according to cultivar groups and in declining order of $\mathrm{Zn}$ concentration in experiment 2 . Data in experiment 1 are values of mixed samples of 2-3 individual plants; data in experiment 2 are presented as means \pm SE, $n=3$. All plants were grown in half-strength Hoagland's nutrient solution containing $2 \mu \mathrm{M} \mathrm{ZnSO}$. Different letters indicate significant differences at $P \leq 0.001$. Significance was determined by ANOVA followed by Student Neuman-Keuls posthoc analysis. The squared correlation coefficients (Correl) were determined between data in the two experiments for each mineral by linear regression

only $50 \%$ relative shoot growth at $300 \mu \mathrm{M} \mathrm{Zn}$ (Table 5). The range of relative growth was different between roots and shoots (Table 5). The $300 \mu \mathrm{M} \mathrm{Zn}$ treatment induced a drastic decrease in root biomass by $65-82 \%$, while this induced only a moderate reduction in shoot biomass of between 6 and $50 \%$.

When determining ZT in terms of root elongation, it became clear that the effect on root biomass was not reflected by an effect on root length (Table 6), as the relative growth calculated for the increase of maximum root length is not consistent with the previously determined ZT based on root dry biomass. Root elongation of accessions L56w and L86w, that showed the highest relative root dry biomass with respectively $35 \%$ and $26 \%$ of the control, was strongly inhibited at $300 \mu \mathrm{M}$ Zn to respectively $11 \%$ and $9 \%$ of the control. Root elongation of all six accessions was inhibited at $100 \mu \mathrm{M} \mathrm{Zn}$ and this inhibition was enhanced at $300 \mu \mathrm{M} \mathrm{Zn}$. The difference in root elongation between accessions decreased with increased $\mathrm{Zn}$ concentration. When plants were grown at $300 \mu \mathrm{M}$ $\mathrm{Zn}$ there was no significant difference in the mean root elongation among the six accessions.

\section{Zn efficiency}

In experiment 2, the six accessions (L56w, L58w, L64w, L66w, L86w, L203w) used in the ZT experiment were also examined for their $\mathrm{Zn}$ efficiency (ZE), i.e. the ability to grow under low Zn supply. Plants began to show typical symptoms of $\mathrm{Zn}$ deficiency, such as interveinal chlorosis, a purple stem and reduced growth, already after growing for 1 week in $\mathrm{Zn}$ deficient medium. After 2 weeks, the 
Table 4 Seed weight (mg per 100 seeds), seed mineral content (ng seed ${ }^{-1}$ ) and dry biomass (mg plant ${ }^{-1}$ ) after 28 days of growth under sufficient $\mathrm{Zn}$ supply of the 21 B. rapa accessions used in experiment 2

\begin{tabular}{|c|c|c|c|c|c|c|c|}
\hline Cultivar group & Acc. & Seed weight & $\mathrm{Zn}$ & $\mathrm{Fe}$ & $\mathrm{Mn}$ & Dry shoot biomass & Dry root biomass \\
\hline \multirow[t]{7}{*}{ Chinese Cabbage } & L107w & 428 & 199 & 289 & 153 & $880 \pm 65$ & $55 \pm 6$ \\
\hline & L113w & 154 & 107 & 145 & 67 & $380 \pm 68$ & $32 \pm 4$ \\
\hline & L64w & 267 & 238 & 309 & 91 & $517 \pm 42$ & $46 \pm 6$ \\
\hline & L127w & 248 & 139 & 153 & 87 & $645 \pm 47$ & $36 \pm 2$ \\
\hline & L140w & 233 & 124 & 214 & 87 & $345 \pm 44$ & $23 \pm 4$ \\
\hline & L23w & 218 & 179 & 227 & 74 & $175 \pm 54$ & $9 \pm 4$ \\
\hline & L146 & 246 & 245 & 237 & 112 & $754 \pm 101$ & $48 \pm 4$ \\
\hline \multirow[t]{6}{*}{ Pak Choi } & L196w & 266 & 176 & 278 & 124 & $474 \pm 98$ & $34 \pm 7$ \\
\hline & L86w & 318 & 222 & 314 & 140 & $422 \pm 29$ & $36 \pm 4$ \\
\hline & L66w & 306 & 189 & 246 & 138 & $601 \pm 10$ & $43 \pm 1$ \\
\hline & L175 & 199 & 134 & 209 & 83 & $321 \pm 41$ & $22 \pm 4$ \\
\hline & L67w & 179 & 143 & 229 & 102 & $361 \pm 14$ & $21 \pm 5$ \\
\hline & L78w & 287 & 242 & 391 & 173 & $449 \pm 38$ & $34 \pm 6$ \\
\hline \multirow[t]{2}{*}{ Mizuna } & L203w & 297 & 221 & 332 & 117 & $413 \pm 117$ & $22 \pm 6$ \\
\hline & L19 & 123 & 73 & 222 & 74 & $606 \pm 97$ & $40 \pm 9$ \\
\hline Wutacai & L56w & 203 & 137 & 202 & 96 & $182 \pm 21$ & $11 \pm 1$ \\
\hline Caixin & L58w & 189 & 85 & 201 & 80 & $465 \pm 56$ & $35 \pm 6$ \\
\hline Zi Caitai & L62w & 202 & 128 & 173 & 92 & $356 \pm 70$ & $29 \pm 1$ \\
\hline Yellow Sarson & L143 & 448 & 261 & 469 & 187 & $342 \pm 41$ & $40 \pm 6$ \\
\hline Rapid Cycling & L144 & 124 & 94 & 88 & 101 & $57 \pm 17$ & $5 \pm 1$ \\
\hline Turnip & L115 & 183 & 141 & 206 & 74 & $434 \pm 3$ & $28 \pm 2$ \\
\hline
\end{tabular}

Fig. 3 Excess $Z$ n stress response of $158 \mathrm{~B}$. rapa accessions grown in halfstrength Hoagland's nutrient solution with $800 \mu \mathrm{M}$ Zn for 14 days. TSP (Toxic Symptom Parameter): 1 = slight chlorosis, still growing; 2 = chlorosis; 3 = severe chlorosis, leaves started withering; $4=$ most of the leaves seared; 5 = dead. Values are means of two or three plants per accession

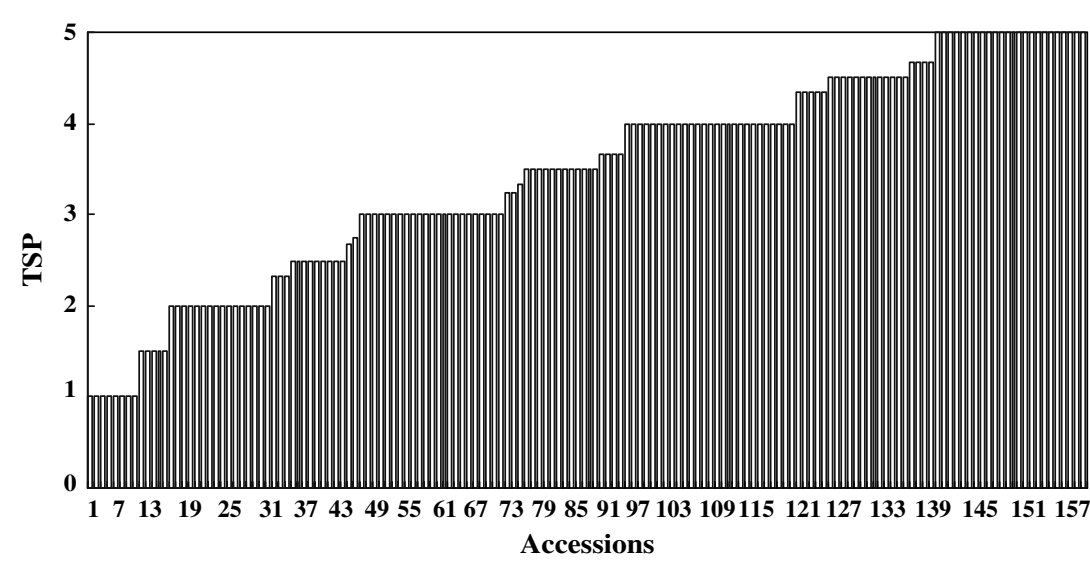

difference in phenotype compared to untreated plants was easily distinguished by eye with the exception of accessions L64w and particularly L56w, which appeared comparatively healthy (Fig. 4).

Both root and shoot dry matter production was reduced in all accessions due to $\mathrm{Zn}$ deficiency (Table 7), but this reduction was much less in L64w for both shoot $(69.8 \%)$ and root $(98.0 \%)$. L64w is therefore considered to be the most zinc efficient accession of the six accessions tested. ZE varied more for shoot biomass (2.6-fold) than for root biomass (1.8-fold). In addition to $\mathrm{ZE}$ we also examined the relative root:shoot biomass ratio (RSR) for the six accessions. Zn deficiency enhanced the RSR in most accessions and thus has a stronger effect on shoot biomass production than on root biomass production. However, since the most $\mathrm{Zn}$ efficient accession L64w has a very similar RSR as the least $\mathrm{Zn}$ efficient accession L86w, there does not seem to be a very strong correlation between ZE and RSR. When comparing ZE based on shoot biomass, root biomass or RSR with seed weight and mineral content per seed (Table 4), no significant correlation was found (data not shown). 
Table 5 Average dry shoot and root biomass ( $\mathrm{mg} \mathrm{plant}^{-1}$ ) and $\mathrm{Zn}$ tolerance (ZT) of shoots and roots of six accessions (Acc.) grown for 14 days in half-strength Hoagland's nutri- ent solution containing $2 \mu \mathrm{M}, 100 \mu \mathrm{M}$ or $300 \mu \mathrm{M} \mathrm{ZnSO}_{4}$. $\mathrm{ZT}$ (in \%) is calculated as relative biomass compared to $2 \mu \mathrm{M} \mathrm{ZnSO}_{4}$

\begin{tabular}{|c|c|c|c|c|c|c|c|c|c|c|}
\hline \multirow[t]{2}{*}{ Acc. } & \multicolumn{2}{|l|}{$2 \mu \mathrm{M}$} & \multicolumn{4}{|l|}{$100 \mu \mathrm{M}$} & \multicolumn{4}{|l|}{$300 \mu \mathrm{M}$} \\
\hline & Shoot & Root & Shoot & ZT & Root & ZT & Shoot & ZT & Root & $\mathrm{ZT}$ \\
\hline L56w & $247 \pm 49$ & $20 \pm 5$ & $257 \pm 28$ & 104 & $15 \pm 3$ & 74 & $231 \pm 20$ & 94 & $7 \pm 1$ & 35 \\
\hline L86w & $441 \pm 58$ & $71 \pm 10$ & $354 \pm 40$ & 80 & $46 \pm 5$ & 65 & $417 \pm 6$ & 94 & $18 \pm 1$ & 26 \\
\hline L58w & $476 \pm 62$ & $62 \pm 12$ & $341 \pm 29$ & 72 & $37 \pm 5$ & 59 & $312 \pm 32$ & 66 & $13 \pm 2$ & 21 \\
\hline L64w & $688 \pm 77$ & $73 \pm 6$ & $491 \pm 67$ & 71 & $48 \pm 7$ & 66 & $429 \pm 61$ & 62 & $14 \pm 3$ & 19 \\
\hline L203w & $660 \pm 44$ & $109 \pm 11$ & $440 \pm 95$ & 67 & $37 \pm 11$ & 34 & $391 \pm 50$ & 59 & $20 \pm 2$ & 18 \\
\hline L66w & $516 \pm 38$ & $58 \pm 6$ & $274 \pm 34$ & 53 & $24 \pm 3$ & 41 & $256 \pm 44$ & 50 & $11 \pm 2$ & 19 \\
\hline
\end{tabular}

Data are presented as means $\pm \mathrm{SE}, n=9$

Table 6 Comparison of root elongation (RE; in $\mathrm{mm}$ ) and relative root growth ( $\mathrm{RG}$; in \%) of six accessions (Acc.) grown in half-strength Hoagland's nutrient solution with $100 \mu \mathrm{M}$ or $300 \mu \mathrm{M} \mathrm{Zn}$ supply for 14 days

\begin{tabular}{llllllr}
\hline Acc. & $2 \mu \mathrm{M}$ & \multicolumn{1}{l}{$100 \mu \mathrm{M}$} & & & $300 \mu \mathrm{M}$ & \\
\cline { 7 - 7 } \cline { 5 - 7 } & $\mathrm{RE}$ & $\mathrm{RE}$ & $\mathrm{RG}$ & & $\mathrm{RE}$ & $\mathrm{RG}$ \\
\hline L56w & $17 \pm 3 \mathrm{c}$ & $13 \pm 3 \mathrm{~b}$ & 77 & & $2 \pm 1 \mathrm{a}$ & 11 \\
L86w & $33 \pm 6 \mathrm{ab}$ & $17 \pm 3 \mathrm{~b}$ & 52 & & $3 \pm 3 \mathrm{a}$ & 9 \\
L58w & $16 \pm 3 \mathrm{c}$ & $13 \pm 4 \mathrm{~b}$ & 82 & & $5 \pm 2 \mathrm{a}$ & 31 \\
L64w & $49 \pm 8 \mathrm{a}$ & $35 \pm 4 \mathrm{a}$ & 72 & & $4 \pm 1 \mathrm{a}$ & 8 \\
L203w & $45 \pm 9 \mathrm{a}$ & $19 \pm 5 \mathrm{~b}$ & 42 & & $11 \pm 4 \mathrm{a}$ & 24 \\
L66w & $29 \pm 6 \mathrm{ab}$ & $12 \pm 5 \mathrm{~b}$ & 41 & & $7 \pm 4 \mathrm{a}$ & 24 \\
\hline
\end{tabular}

$\mathrm{RG}$ is expressed as percentage of the growth at $2 \mu \mathrm{M} \mathrm{Zn}$. Data are presented as means $\pm \mathrm{SE}, n=9$. Values followed by different letters are significantly different at $P \leq 0.05$. Significance is determined by ANOVA followed by Student Neuman-Keuls posthoc analysis

Shoot $\mathrm{Zn}$ concentration did not differ among the six accessions after plants were grown under $\mathrm{Zn}$ deficient condition for 15 days with a reduction of $76-84 \%$ (Table 8 ). There was no significant correlation between $\mathrm{ZE}$ and the shoot $\mathrm{Zn}$ concentration at $0 \mu \mathrm{M}$ or $2 \mu \mathrm{M} \mathrm{Zn}$ (data not shown). In general, both shoot $\mathrm{Fe}$ and $\mathrm{Mn}$ concentrations were increased under $\mathrm{Zn}$ deficient condition when compared to Zn sufficient condition (Table 8). Four out of six accessions showed a significant increase in shoot Mn concentration, while two of these accessions also increased significantly in Fe concentration. There was no correlation between $\mathrm{ZE}$ and shoot $\mathrm{Mn}$ or $\mathrm{Fe}$ concentration of plants grown at 0 or $2 \mu \mathrm{M} \mathrm{Zn}$ (data not shown).

\section{Discussion}

In total 117 B. rapa accessions were screened for $\mathrm{Zn}, \mathrm{Mn}$ and $\mathrm{Fe}$ accumulation characteristics as a general survey for genotypic variation among $B$. rapa vegetables. This survey showed that there is considerable genotypic variation for shoot $\mathrm{Zn}$, $\mathrm{Mn}$ and $\mathrm{Fe}$ concentration in B. rapa. This variation is not limited to one or a few cultivar groups and there is also no clear correlation between mineral concentration and cultivar group. When the selected accessions were re-examined at a second location, different results were obtained for some of these accessions and in general the correlation between locations was lower than expected. This does not reflect errors in sampling or measuring mineral concentrations, but largely illustrates the difficulty associated with studying a trait that is easily affected by genotype $x$ environment
Fig. 4 Visible phenotypic response of $B$. rapa accessions to $\mathrm{Zn}$ deficiency. Plants were grown in halfstrength Hoagland's nutrient solution for 15 days with $(2 \mu \mathrm{M} Z \mathrm{Zn} ;+\mathrm{Zn})$ or without $\mathrm{ZnSO}_{4}$ supply (0 $\mu \mathrm{M} \mathrm{Zn} ;-\mathrm{Zn})$

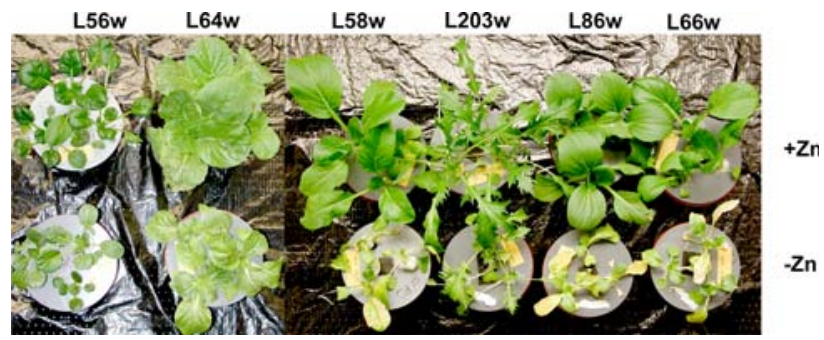


Table 7 Average dry biomass (in $\mathrm{mg} \mathrm{plant}^{-1}$ ), $\mathrm{Zn}$ efficiency $(\mathrm{ZE}$; in $\%)$ of roots and shoots and the relative root:shoot biomass ratio (RSR) of six accessions (Acc.) grown for 15 days in half-strength Hoagland's nutrient solution without $(0 \mu \mathrm{M})$ or with $(2 \mu \mathrm{M}) \mathrm{Zn}$ supply

\begin{tabular}{|c|c|c|c|c|c|c|c|c|c|}
\hline \multirow[t]{2}{*}{ Acc. } & \multicolumn{3}{|l|}{ Root } & \multicolumn{3}{|l|}{ Shoot } & \multicolumn{3}{|c|}{ Root:Shoot } \\
\hline & $0 \mu \mathrm{M}$ & $2 \mu \mathrm{M}$ & $\mathrm{ZE}$ & $0 \mu \mathrm{M}$ & $2 \mu \mathrm{M}$ & $\mathrm{ZE}$ & $0 \mu \mathrm{M}$ & $2 \mu \mathrm{M}$ & RSR \\
\hline L64w & $44 \pm 1$ & $45 \pm 6$ & 98.0 & $379 \pm 26$ & $543 \pm 32$ & 69.8 & 0.113 & 0.083 & 1.4 \\
\hline L66w & $15 \pm 2$ & $25 \pm 4$ & 60.0 & $140 \pm 12$ & $290 \pm 31$ & 48.5 & 0.107 & 0.086 & 1.2 \\
\hline L56w & $19 \pm 1$ & $29 \pm 3$ & 66.0 & $160 \pm 11$ & $352 \pm 11$ & 45.4 & 0.094 & 0.082 & 1.2 \\
\hline L203w & $20 \pm 1$ & $52 \pm 4$ & 38.7 & $276 \pm 30$ & $647 \pm 49$ & 42.9 & 0.072 & 0.080 & 0.9 \\
\hline L58w & $23 \pm 4$ & $53 \pm 6$ & 43.4 & $175 \pm 40$ & $434 \pm 42$ & 42.7 & 0.131 & 0.122 & 1.1 \\
\hline L86w & $24 \pm 3$ & $48 \pm 2$ & 50.6 & $197 \pm 23$ & $529 \pm 6$ & 37.2 & 0.122 & 0.091 & 1.3 \\
\hline
\end{tabular}

$\mathrm{ZE}$ is determined as the biomass at $0 \mu \mathrm{M} \mathrm{Zn}$ compared to $2 \mu \mathrm{M} \mathrm{Zn}$ (in \%). RSR is determined as the root:shoot ratio (Root:Shoot) at $0 \mu \mathrm{M} \mathrm{Zn}$ compared to $2 \mu \mathrm{M} \mathrm{Zn}$ (in \%). Data are presented as means $\pm \mathrm{SE}, n=3$

Table 8 Shoot $\mathrm{Zn}, \mathrm{Fe}$ and Mn concentrations $\left(\mu \mathrm{g} \mathrm{g}^{-1} \mathrm{~d}\right.$. wt.) of plants grown for 15 days in half-strength Hoagland's nutrient solution without $(0 \mu \mathrm{M})$ or with $(2 \mu \mathrm{M}) \mathrm{Zn}$ supply

\begin{tabular}{|c|c|c|c|c|c|c|}
\hline \multirow[t]{2}{*}{ Acc } & \multicolumn{2}{|l|}{$\mathrm{Zn}$} & \multicolumn{2}{|l|}{$\mathrm{Fe}$} & \multicolumn{2}{|l|}{ Mn } \\
\hline & $0 \mu \mathrm{M}$ & $2 \mu \mathrm{M}$ & $0 \mu \mathrm{M}$ & $2 \mu \mathrm{M}$ & $0 \mu \mathrm{M}$ & $2 \mu \mathrm{M}$ \\
\hline L64w & $6 \pm 0$ & $33 \pm 1$ & $90 \pm 17$ & $45 \pm 2$ & $51 \pm 2$ & $53 \pm 2$ \\
\hline L66w & $8 \pm 1$ & $41 \pm 2$ & $297 \pm 135$ & $43 \pm 1$ & $164 \pm 30 *$ & $43 \pm 1$ \\
\hline L56w & $7 \pm 1$ & $43 \pm 3$ & $131 \pm 29 *$ & $45 \pm 2$ & $128 \pm 18^{*}$ & $65 \pm 1$ \\
\hline L203w & $6 \pm 1$ & $27 \pm 1$ & $59 \pm 8$ & $45 \pm 2$ & $65 \pm 5 *$ & $46 \pm 3$ \\
\hline L58w & $7 \pm 1$ & $36 \pm 2$ & $99 \pm 54$ & $52 \pm 1$ & $88 \pm 16$ & $66 \pm 1$ \\
\hline L86w & $6 \pm 0$ & $32 \pm 1$ & $84 \pm 6^{*}$ & $50 \pm 4$ & $123 \pm 9 *$ & $50 \pm 4$ \\
\hline
\end{tabular}

Data are presented as means $\pm \mathrm{SE}, n=3$

* significantly different from $2 \mu \mathrm{M} \mathrm{Zn}$ supply $(P \leq 0.05)$. Significance is determined by one-way ANOVA

interactions, which is often the case for mineral accumulation. Genetic variation within accessions is another factor that may have caused differences in mineral concentration. Although the accessions had been propagated for some generations in the resource collection they originated from, the occurrence of self-incompatibility, which is common in B. rapa, is expected to maintain some genetic variation within each accession.

Previous studies revealed variation ranges of $10-60 \mu \mathrm{g} \mathrm{g}^{-1}$ for $\mathrm{Zn}$ and $10-90 \mu \mathrm{g} \mathrm{g}^{-1}$ for $\mathrm{Fe}$ in seeds (Beebe et al. 2000; Graham et al. 1999; Graham et al. 1997; Banziger and Long 2000). Kopsell et al. (2004) reported that leaf $\mathrm{Zn}$ concentration based on fresh weight ranged from 29.1 to $71.9 \mathrm{mg} \mathrm{g}^{-1}$ and $\mathrm{Fe}$ concentration ranged from 53.1 to $114.2 \mathrm{mg} \mathrm{g}^{-1}$ in $B$. oleracea vegetables. In the present study a wider variation range (7-fold) and higher highest concentration were found for $\mathrm{Zn}$ and $\mathrm{Fe}$ in $B$. rapa shoots. Of course this may reflect a physiological difference in the accumulation process between shoot and seed. Shoot accumulation largely depends on xylem transport, whereas seed accumulation requires additional phloem transport. Also different from screening plants in hydroponic culture, as was done in our study, the investigations on above staple crops were all carried out in soil, which might cause lower mineral availability. Seed weight and mineral content influence plant growth at the early vegetative stage (Rengel and Graham 1995a) and therefore affect shoot mineral accumulation. In the present study the correlation of Mn concentration in shoot and Mn content in seed supports the previous conclusion, however, there was no correlation between shoot concentration and seed content for $\mathrm{Zn}$ and Fe. Thus, the variation for $\mathrm{Zn}$ and $\mathrm{Fe}$ concentration as observed in this study suggests that there is sufficient genetic variation to dissect the genetic mechanism controlling shoot $\mathrm{Zn}$ and Fe accumulation by quantitative trait locus (QTL) analysis and/or to improve $\mathrm{Zn}$ and Fe content in B. rapa vegetables by breeding.

In addition to growth under sufficient $\mathrm{Zn}$ supply we also studied the response to $\mathrm{Zn}$ excess and deficiency in B. rapa. Both relative shoot and root growth have been suggested as good indices of tolerance to excess $\mathrm{Zn}$ in different species (Bert et al. 2000; Escarre et al. 2000; Meerts and Van Isacker 1997; Schat and Ten Bookum 1992; Yang et al. 2004). The comparable range in variation of $\mathrm{ZT}$ we observed, which was based on dry shoot and root biomass, suggests that the same holds for $B$. rapa. However, ZT determined by maximum root 
length did not correlate with the ZT determined by dry biomass, although both root elongation and biomass increase were inhibited in a concentration-dependent manner when exposed to toxic $\mathrm{Zn}$ concentrations. Our results thus support the suggestion by Ebbs and Kochian (1997) that the toxic effect of excess $\mathrm{Zn}$ on the root development in Brassica ssp. has more effect on lateral root elongation than on lateral root density.

To examine the response to deficient $\mathrm{Zn}$ exposure, relative shoot growth was reported as a suitable index to determine Zn efficiency (Cakmak et al. 1999; Grewal et al. 1997; Hacisalihoglu et al. 2004; Rengel and Römheld, 2000), although also the relative root:shoot biomass ratio (RSR) has been suggested to be adequate (Rengel and Graham, 1995b). In the present study, both the relative shoot and relative root biomass index were effective in distinguishing differences in $\mathrm{Zn}$ efficiency. Accession L64w clearly stood out as the least affected by low $\mathrm{Zn}$ supply when compared to the other accessions. The RSR generally increases under Zn deficiency as an initial response to $\mathrm{Zn}$ deficiency (Grewal et al. 1997; Khan et al. 1998; Loneragan et al. 1987). Higher RSRs correlating with Zn efficiency have also been reported for B. napus and B. juncea (Grewal et al. 1997). A comparable result was obtained in the present study, with the exception that, based on biomass production, the relatively $\mathrm{Zn}$ inefficient accession L86w had a similarly high RSR as the Zn efficient accession L64w. Considering this, the RSR does not seem to be the optimal Zn efficiency index for B. rapa.

While variation for both ZT and Zn efficiency was observed among the six accessions, there was no significant correlation between these traits. The absence of correlation between $\mathrm{Zn}$ efficiency and seed weight, seed mineral content or shoot mineral concentration also indicates that $\mathrm{Zn}$ efficiency is genetically independent from these traits. When grown under $\mathrm{Zn}$ deficiency, the limited $\mathrm{Zn}$ supply resulted in an almost uniform shoot $\mathrm{Zn}$ concentration for all accessions that was below $10 \mu \mathrm{g}^{-1} \mathrm{~d}$. wt. Since a leaf $\mathrm{Zn}$ concentration below $10-15 \mu \mathrm{g} \mathrm{g}^{-1} \mathrm{~d}$. wt. is considered to be the critical $\mathrm{Zn}$ deficiency level for normal plant growth (Marschner 1995), this explains the negative effect of the $\mathrm{Zn}$ deficiency treatment on growth of the B. rapa accessions.
In addition to an effect on $\mathrm{Zn}$ concentration, we found that when plants were grown under $\mathrm{Zn}$ deficient conditions, both Fe and especially $\mathrm{Mn}$ concentration in shoots increased, comparable to what has been found in wheat (Rengel and Graham 1996) or Arabidopsis (van de Mortel et al. 2006). Most of the known metal transporters belong to large gene families covering a broad range of metal specificities. Several of the $\mathrm{Zn}$ transporters can also transport Fe or Mn (Connolly et al. 2002; Mills et al. 2003; Vert et al. 2001). Decreased shoot Fe and Mn concentration was found for Brassica plants grown in high-level $\mathrm{Zn}$ conditions (Ebbs and Kochian 1997). This is also in line with the correlations we observed between shoot $\mathrm{Zn}, \mathrm{Fe}$ and $\mathrm{Mn}$ concentrations when plants were grown under sufficient $\mathrm{Zn}$ supply (Fig. 2). In both experiments (sufficient and deficient $\mathrm{Zn}$ supply), the strongest correlation was found between $\mathrm{Zn}$ and $\mathrm{Mn}$, suggesting that $\mathrm{Zn}$ and $\mathrm{Mn}$ accumulation share more common elements than $\mathrm{Fe}$ and $\mathrm{Mn}$ or $\mathrm{Fe}$ and $\mathrm{Zn}$ accumulation.

Another observation was that the difference in $\mathrm{Zn}$ efficiency based on biomass was not fully reflected in the visual appearance of the accessions. Accessions L64w and L56w seemed to suffer little from deficient $\mathrm{Zn}$ supply in terms of plant size and degree of leaf senescence or yellowing of the leaves (Fig. 4). However, when scored for biomass production, L56w did not perform better than the other accessions with a comparable $\mathrm{ZE}$ value. A similar difference in visible appearance and biomass production was previously found for wheat (Genc and McDonald 2004). This suggests that the plant response to low zinc can act at different levels and the effect on biomass production is not always easily visible by eye. It also shows that visual selection of $\mathrm{Zn}$ efficient plant genotypes by breeders may be misleading with respect to yield.

Based on the screening of a large set of $B$. rapa accessions, we conclude there is substantial genotypic variation for $\mathrm{Zn}, \mathrm{Fe}$ and $\mathrm{Mn}$ accumulation and for tolerance to excessive or deficiency inducing levels of $\mathrm{Zn}$. Relative shoot and root growth calculated on dry biomass yield are suitable indices both for the evaluation of excess ZT and for $\mathrm{Zn}$ efficiency. There is a close relationship 
between $\mathrm{Zn}, \mathrm{Mn}$ and $\mathrm{Fe}$ accumulation. Our results underline that breeding for improved $\mathrm{Zn}$ content, whether or not in combination with enhanced fertilization with $\mathrm{Zn}$, is likely to substantially increase the $\mathrm{Zn}$ content of $B$. rapa vegetables and thus offer a desirable $\mathrm{Zn}$ supplementation to a vegetarian human diet.

Acknowledgements We thank Dr. Xixiang Li (Institute of Vegetables and Flowers of the Chinese Academy of Agricultural Sciences, Beijing, China); the Dutch Crop Genetic Resources Centre (CGN) (Wageningen, NL) and Dr. T. Osborn (University of Wisconsin, Madison, USA) for kindly supplying the accessions used in this study. This research is supported by the Wageningen University-Chinese Academy of Agricultural Sciences INREF Joint PhD Training Programme, the Centre for Biosystems Genomics and The Opening Lab of Vegetable Genetics and Physiology of the Ministry of Agriculture, P. R. China.

\section{References}

Banziger M, Long J (2000) The potential for increasing the iron and zinc density of maize through plant breeding. Food Nutr Bull 21:397-400

Beebe S, Gonzalaz AV, Rengifo J (2000) Research on trace minerals in the common bean. Food Nutr Bull 21:387391

Bert V, Macnair MR, DeLaguerie P, Saumitou-Laprade P, Petit D (2000) Zinc tolerance and accumulation in metallicolous and non metallicolous populations of Arabidopsis halleri (Brassicaceae). New Phytol 146:225233

Cakmak I, Sari N, Marschner H, Kalayci M, Yilmaz A, Eker S, Gülüt KY (1996) Dry matter production and distribution of $\mathrm{Zn}$ in bread and durum wheat genotypes differing in Zn efficiency. Plant Soil 180:173-181

Cakmak I, Tolay I, Ozdemir A, Ozkan H, Oztürk L, Kling CI (1999) Differences in zinc effciency among and within diploid, tetraploid and hexaploid wheats. Ann Bot 84:163-171

Connolly EL, Fett JP, Guerinot ML (2002) Expression of the IRT1 metal transporter is controlled by metals at the levels of transcript and protein accumulation. Plant Cell 14:1347-1357

Coolong TW, Randle WM (2003) Zn concentration in hydroponic solution culture influences zinc and sulfur accumulation in Brassica rapa L. J Plant Nutr 26:949-959

Ebbs SD, Kochian LV (1997) Toxicity of zinc and copper to Brassica species: Implications for phytoremediation. J Environ Qual 26:776-781

Escarre J, Lefebvre C, Gruber W, Leblanc M, Lepart J, Riviere Y, Delay B (2000) Zinc and cadmium hyperaccumulation by Thlaspi caerulescens from metalliferous and nonmetalliferous sites in the Mediterranean area: implications for phytoremediation. New Phytol 145:429-437
Genc Y, McDonald GK (2004) The potential of synthetic hexaploid wheats to improve zinc efficiency in modern bread wheat. Plant Soil 262:23-32

Gomez-Campo C, Prakash S (1999) Origin and domestication. In: Gomez-Campo C. (ed) Biology of Brassica Coenospecies. Elsevier Science BV, Amsterdam, The Netherlands, pp 33-52

Graham RD, Ascher JS, Hynes SC (1992) Selecting Zn efficient cereal genotypes for soils of low $\mathrm{Zn}$ status. Plant Soil 146:241-250

Graham RD, Senadhira D, Ortiz-Monasterio I (1997) A strategy for breeding staple-food crops with high micronutrient density. Soil Sci Plant Nutr 43:11531157

Graham RD, Senadhira D, Beebe S, Iglesias C, Monasterio I (1999) Breeding for micronutrient density in edible portions of staple food crops: conventional approaches. Field Crop Res 60:57-80

Grewal HS, Stangoulis JCR, Potter TD, Graham RD (1997) Zinc efficiency of oilseed rape (Brassica napus and B. juncea) genotypes. Plant and Soil 191:123-132

Hacisalihoglu G, Kochian LV (2003) How do some plants tolerate low levels of soil zinc? Mechanisms of zinc efficiency in crop plants. New Phytol 159:341-350

Hacisalihoglu G, Ozturk L, Cakmak I, Ross MW, Kochian LV (2004) Genotypic variation in common bean in response to zinc deficiency in calcareous soil. Plant Soil 259:71-83

He PP, Lv XC, Wang GY (2004) Effect of Se and Zn supplementation on the antagonism against $\mathrm{Pb}$ and $\mathrm{Cd}$ in vegetables. Environ Int 30:167-172

Khan HR, McDonald GK, Rengel Z (1998) Chickpea genotypes differ in their sensitivity to $\mathrm{Zn}$ deficiency. Plant Soil 198:11-18

Kopsell DE, Kopsell DA, Lefsrud MG, Curran-Celentano J (2004) Variability in elemental accumulations among leafy Brassica oleracea cultivars and selections. J Plant Nutri 27:1813-1826

Liu Z (1994) Regularities of content and distribution of zinc in soils of China. Scientia Agricultura Sinica 27:30-37

Liu WH, Zhao JZ, Ouyang ZY, Soderlund L, Liu GH (2005). Impacts of sewage irrigation on heavy metal distribution and contamination in Beijing, China. Environ Int 31:805-812

Loneragan JF, Kirk GJ, Webb MJ (1987) Translocation and function of $\mathrm{Zn}$ in roots. J Plant Nutr 10:1247-1254

Marschner H (1995). Mineral nutrition of higher plants. Academic Press. London, UK, p 352

Ma G, Li Y, Jin Y, Du S, Kok FJ, Yang X. Assessment of zinc intake adequency and food source of people in China. Public Health Nutrition (in press)

Meerts P, Van Isacker N (1997) Heavy metal tolerance and accumulation in metallicolous and non-metallicolous populations of Thlaspi caerulescens from continental. Europe. Plant Ecol 133:221-231

Mills RF, Krijger GC, Baccarini PJ, Hall JL, Williams LE (2003) Functional expression of AtHMA4, a P1B-type ATPase in the $\mathrm{Zn} / \mathrm{Co} / \mathrm{Cd} / \mathrm{Pb}$ subclass. Plant J 35:164175 
Nan ZR, Zhao CY (2000) Heavy metal concentrations in grey calcareous soils of Baiyin region, Gansu province, P.R.China. Water Air Soil Pollut 118:131-141

Opena RT, Kuo CG, Yoon JY (1988) Breeding and seed production of Chinese cabbage in the tropics and subtropics. Technical Bulletin No. 17. AVRDC, Shanhus, Taiwan

Rengel Z, Graham RD (1995a) Importance of seed Zn content for wheat growth on Zn-deficient soil. I Vegetative growth. Plant Soil 173:259-266

Rengel Z, Graham RD (1995b) Wheat genotypes differ in $\mathrm{Zn}$ efficiency when grown in chelate-buffered nutrient solution. I. Growth. Plant Soil 176:307-316

Rengel Z, Graham RD (1996) Uptake of zinc from chelatebuffered nutrient solutions by wheat genotypes differing in zinc efficiency. J Exp Bot 47:217-226

Rengel Z, Römheld V (2000) Differential tolerance to Fe and $\mathrm{Zn}$ deficiencies in wheat germplasm. Euphytica 113:219-225
Schat H, Ten Bookum WM (1992) Genetic control of copper tolerance in Silene vulgaris. Heredity 63:219-229

van de Mortel JE, Almar Villanueva L, Schat H, Kwekkeboom J, Coughlan S, Moerland PD, Ver Loren van Themaat E, Koornneef M, Aarts MGM (2006) Large expression differences in genes for iron and zinc homeostasis, stress response, and lignin biosynthesis distinguish roots of Arabidopsis thaliana and the related metal hyperaccumulator Thlaspi caerulescens. Plant Physiol 142:1127-1147

Vert G, Briatt JF, Curie C (2001) Arabidopsis IRT2 gene encodes a root periphery iron transporter. Plant $\mathbf{J}$ 26:181-189

Yang XE, Long XX, Ye HB, He ZL, Calvert DV, Stoffella PJ (2004) Cadmium tolerance and hyperaccumulation in a new Zn-hyperaccumulating plant species (Sedum alfredii Hance). Plant Soil 259:181-189 